2019-11-04

\title{
Making time for food when 'doing time'; how enhanced status prisoners counter the indignity of prison foodways
}

\section{Parsons, J}

http://hdl.handle.net/10026.1/15159

\subsection{6/j.appet.2019.104507}

Appetite

Elsevier

All content in PEARL is protected by copyright law. Author manuscripts are made available in accordance with publisher policies. Please cite only the published version using the details provided on the item record or document. In the absence of an open licence (e.g. Creative Commons), permissions for further reuse of content should be sought from the publisher or author. 
This is a final author's draft of an article accepted for publication in a Special Issue of Appetite on 'Prison Foodways', volume 146, March 2020

\title{
https://doi.org/10.1016/i.appet.2019.104507
}

\section{By: Dr J M Parsons}

\section{Accepted for publication 4/11/2019}

Title: Making time for food when 'doing time'; how enhanced status prisoners counter the indignity of prison foodways.

\begin{abstract}
In contemporary neo-liberal societies, forms of responsible individualism and approaches to everyday foodways that reify healthy home-cooked food prepared from scratch, eaten together around a table are imbued with high cultural capital. What are the implications of this for criminalised individuals incarcerated in a prison system in England and Wales, that works with extremely low budgets, makes heavy use of pre-packaged convenience food and serves food to prisoners in their cells? Indeed, findings from Her Majesty's Inspectorate for Prison Report on food (2016:13), claims that 'the quantity and quality of the food provided [in prison] is insufficient, and the conditions in which it is served and eaten undermine respect for prisoners' dignity', which they argue has implications in terms of increasing the marginalisation and alienation of the prison population from the 'free community'. In this paper I draw on data from 39 in depth interviews at a resettlement scheme in England, conducted with 18 prisoners released on temporary licence from the resettlement wing of a closed and segregated Category $C$ male prison. The enhanced status of prisoners and the benefits of being on the resettlement wing affords opportunities in relation to everyday foodways not available to regular prisoners. Their narrative accounts of prison foodways exemplify some of the HMIP findings and demonstrate how an enhanced prisoner status can counter notions of food as threat and poison, through systems of bartering, solidarity and recompense.
\end{abstract}

\section{Introduction}

The fieldwork for this paper was conducted against a background that considers everyday foodways a powerful means of drawing distinctions between social groups with early food experiences significant in shaping identity (Parsons 2015). Indeed, 'food looks like an object but is actually a relationship [...] endlessly interpretable, as gift, threat, poison, recompense, barter, seduction, solidarity, suffocation' (Eagleton 1998:204). Moreover, when we eat, we are not only consuming nutrients, but gustatory experiences, cultural meanings and symbols (Beardsworth and Keil, 1997). In this context food can be treated as a code, that includes messages about social events and relations like 'hierarchy, inclusion and exclusion, boundaries and transactions across boundaries' (Douglas 1975:61). Foods can also be seen as signs in a system of communication (Barthes 1979), often used in advertising for example to denote antinomies of taste such as 'novelty and tradition', 'health and indulgence', 'economy and extravagance' and 'convenience and care' (Warde 1997:173).

Eating as Warde (2016) reminds us "is a form of consumption, a means of communication with others, signalling self-identity, through [the] cultivation of distinct 'lifestyles' and in 'doing' the practice of eating" (Warde, 2016:09). The term 'foodways' therefore has a dual 
meaning; it highlights the significance of modes of practice or ways of doing food, as well as movement and direction across time (history) and space (culture) (Parsons 2015). It usually refers to the production and distribution of food at a macro level and is used in anthropology when exploring food cultures or shared common beliefs, behaviours and practices relating to the production and consumption of food (Counihan 1999). Here I also consider foodways at a micro level, to reflect the multiplicity of ways of 'doing' food that incorporates all aspects of everyday food practices, from acquiring food, preparing, cooking, sharing and eating together.

Moreover, foodways can be considered an important aspect of an individual's cultural habitus (Bourdieu 1984), which is inculcated from birth and draws upon forms of economic, cultural, social and symbolic capital (Parsons, 2015, 2016a). Indeed, foodways are narratives of relational affectation, or how we learn to know food, with our food preferences embedded, produced and maintained through the practice of doing 'tastes', over and over again (Carolan 2011:6). These foodways are therefore concerned with 'doing' food and food practices; these can be routinised and seemingly unconscious but are essentially part of a pattern of consumption that signifies status (Warde 2016). Accordingly, foodways inculcate a cultural habitus through the repetition, reproduction and reinforcement of values and tastes (Bourdieu 1984). Foodways are therefore significant for inculcating class tastes (Bourdieu 1984), table manners (Visser 1991), and providing a theatre for the civilising of appetites (Elias 1978, Mennell 1985). If appropriate foodways have not been instilled it has implications for identity and status (Parsons 2015). In contemporary, neo-liberal societies that value responsible individualism, appropriate middle-class foodways tend to emphasise healthy meals cooked from scratch and eaten together around a table (Parsons 2014, 2015, 2016a, 2018a). Hence, the manner of presenting, serving and eating food, or everyday foodways fulfils a social function of legitimising social difference, of marking boundaries and fields of distinction between groups (Bourdieu, 1984:6). This is especially pertinent when considering prison foodways, as "prisoners experience the official prison food as a continuation of the more general attack on their identity that prison entails" (Ugelvik 2011: 47).

This raises questions in relation to how people use their everyday foodways in prison to counter threats to selfhood and reinstate a sense of agency, autonomy and status. Indeed, criminalised individuals remain a highly stigmatised group, with the act of criminalisation a source of 'symbolic and structural stigma, realised in individual interactions and structurally embedded in cultural values, practices and institutions of society' (Hannem and Bruckert 2012:10). The impact of stigma on identity and the adoption of strategies of identity management, such as 'passing' and/or 'concealment' have been well documented (Goffman 1963). How individuals manage and/or restore a positive sense of self through their foodways in prison is therefore significant. Moreover, prison foodways have a role to play in maintaining and/or re-establishing social and cultural capital for those looking to distance themselves from the stigma of being a prisoner?

In this paper I draw on data from fieldwork from externally funded consecutive research fellowships, one of which is on-going at a resettlement scheme (RS) that works with men released on temporary license (ROTL) from the local prison (referred to as trainees). This rich qualitative data provides a unique insight into the lived experience of prison foodways 
from a resettlement wing for prisoners with 'enhanced status' in a closed and segregated male category $C$ prison in England. It demonstrates how powerful foodways can be for symbolising belonging and as a process of identification. Although as Douglas (1984) notes whilst food may be seen as a metaphor, a symbol or a vehicle of communication, the meal remains a physical as well as social event (Beardsworth and Keil 1997:63). Hence, the manner in which meals are prepared, served and eaten across the prison estate is also relevant, as this reinforces the notion that prisoners are perhaps underserving of 'good' nutritious food prepared with care.

In this paper I explore the experience of prison foodways from the perspective of enhanced status prisoners from the resettlement wing of a category $C$ prison in England, following Eagleton's (1998:204) notion of food as 'an endlessly interpretable relationship'. Firstly, I consider prison foodways as threat and poison and secondly how these particular prisoners respond to these perceived threats through food as barter, solidarity and recompense. Prior to this, I outline some of the issues related to identity and selfhood as detailed in general prison research as well as highlighting some existing research findings in the field of prison food/foodways. There is also a short methodological section giving brief details of the two externally funded research projects that enabled these findings to emerge.

\section{Background}

Incarceration, identity and prison foodways

There is a long history of research carried out inside penal institutions with the impact of incarceration on prisoner identities well documented (Jewkes 2002, Jewkes and Johnston 2006, Jewkes 2012), notably in terms of the pains of imprisonment (Sykes 1958), assaults upon the self (Goffman 1961) and the need to put on emotional masks or fronts (Crewe et al 2014). Sykes (1958) describes the 'pains of imprisonment' as chiefly comprising five 'deprivations' to which prisoners must respond/adapt. These include deprivation of liberty and social acceptance; goods and services or material possessions; heterosexual relationships; personal autonomy and personal security. This is a 'dehumanising process' (Jewkes 2002:2) that leads to a 'mortification of the self' (Goffman 1961b). Accounts of prison life therefore tend to demonstrate how prisoners put on emotional masks or fronts in order to counter the threats and 'assaults upon the self' (Goffman 1961:68) (Crewe et al 2014). In order to survive the prison experience, 'assimilation involves the suspension of pre-institutional identities and the temporary construction of inauthentic prison identities to mask the true self' (Jewkes 2002:134). Indeed, individuals feel pressure to conform and comply, which further 'undermine(s) the prisoners personal and social identity' (Jewkes 2012: 47).

Prison foodways are therefore not just about gustatory experiences, but are culturally mediated social practices, which are significant for maintaining a sense of self for people in prison. The prison food system in England and Wales is similar to that in the US; it is a form of symbolic punishment as prisoners' lack control over when, where and with whom they can eat. It is also a type of concrete punishment as it relates directly to material deprivation, in terms of 'what is' available to eat (Smoyer and Lopes 2017). Moreover, as in Norwegian prisons, 'prisoners experience the official prison food as a continuation of the more general attack on their identity that imprisonment entails', which can be countered by a celebratory performativity around illicit food preparation (Ugelvik 2011:47). For example, creating meals 
in kettles (kettle cooking) or preparing jailhouse hooch (for sale or personal consumption) becomes an opportunity to exert power and control, whilst flouting the rules, thereby countering threats to self and reinstating a sense of agency (Ugelvik 2011).

In this context food in prison can become a source of resistance and conflict but can also be used as a commodity loaded with cultural symbolism (Valentine and Longstaff 1998). In Godderis' (2006) research, she explores food-based resistance in a prison setting in Canada. Interviewing sixteen prisoners she found the majority complained of the monotonous and repetitive nature of the food, inability to access ethnic dishes and a lack of control over how the food was cooked. Spaces of resistance included the dining room, where there were often incidents of violence and disputes over seating arrangements. Following Godderis (2006) Ugelvik (2011) identifies processes of adaptation and resistance in order to counter the threats to self and to reinstate a sense of agency. On the other hand, in institutional settings, everyday foodways can become sources of domination and resistance. As Godderis (2006) notes, in her study on Canadian prison foodways, these can be either individual or group processes that challenge the prison (food) system or reinstate a sense of agency for the subjugated.

The importance of food in prison was identified by her Majesty's Inspectorate for Prisons (HMIP) (England and Wales), who issued a report on 'food', for their 'Life Inside' series. They identified how 'normal' opportunities for eating was limited, as "food is often served out of synchronicity with the wider population, for example lunch can be served as early as 11:10am and dinner at 4:15pm (HMIP, 2016:08)". The provision for spending on food was variable across the prison estate and reported to be inadequate. Indeed, based on their findings, they made four recommendations (i) that there should be a minimum standard of nutritional values and conditions under which food is consumed (with advice from the relevant professional bodies), (ii) new prisons should be configured to enable eating together, (iii) prison governors should provide more self-catering/cooking opportunities (especially for long-term prisoners), (iv) governors should arrange meal times at 'normal' times of the day. The report and its recommendations highlight the significance of everyday prison foodways in reifying the social position of prisoners. HMIP concluded that "the quantity and quality of the food provided [in prison] is insufficient, and the conditions in which it is served and eaten undermine respect for prisoners' dignity" (2016:13). This has implications in terms of increasing the marginalisation and alienation of the prison population from the 'free community' (HMIP, 2016:11).

\section{Methods:}

Between October 2015 and May 2019, I conducted a series of 39 interviews with 18 serving prisoners during their placements at a resettlement scheme (RS) in a rural location outside of the prison estate. These were conducted initially as part of two consecutive externally funded research fellowships, which are detailed below. However, the success of the second fellowship; the Photographic electronic-Narrative (PeN) project is such that it is on-going, and I am still engaged albeit on a part time basis in interviewing trainees at the RS for this project. This is being done in order to capture the lived experience of time spent at the RS and to consider the impact or otherwise of this on identity. In some of the prisoners' narratives, threats to self are conceptualised in relation to their everyday foodways, as institutionalised settings make little allowance for personal preferences or cultural norms 
and values. In this particular prison environment, there is also a perceived threat of contamination from those tasked with preparing the food. Overall, analysis of the narratives raises questions regarding the importance of everyday foodways for individual identity, especially when these are threatened by institutionalised practices. How far do prison foodways, as experienced by prisoners on the resettlement wing of a category C closed and segregated prison in England, deviate from what might be considered 'normal' socially acceptable cultural food practices? Does it matter? What rights should prisoners have to an adequate and nutritious diet or should prison food be one of the pains of imprisonment? How do prisoners in this sample maintain or re-establish a sense of self beyond the criminalised label? How do they counter the threats of 'contamination' and re-establish social and cultural norms in light of institutionalised foodways?

The interviews were conducted at a resettlement scheme (RS), that offers support to men released on temporary licence (ROTL) from the local prison on work placements and others (men and women) on community sentences, who are referred through probation, collectively called trainees by the RS. Trainees receive ongoing, long-term support throughout their prison terms and community sentences. This also continues once released into the community after punishment and for many even after graduating from the RS itself. The men who choose a placement at the RS are from the resettlement wing of the local prison, which houses 34 men over two floors out of a total prison population of around 750. This wing is for men who have progressed through the prison system of incentives and earned privileges for good behaviour, from basic, entry, standard to enhanced prisoner status. This is significant as the men on the resettlement wing have worked hard within the system to become enhanced prisoners and are keen to maintain this status. The prison itself is a closed and segregated category C prison, which means "prisoners who have a sexual conviction are intentionally separated from other prisoners [segregated under rule 45] and held in Vulnerable Prisoner Units (VPUs)" (McNaughton Nichols and Webster 2018:01). VPU prisoners, even with enhanced status are housed separately and are ineligible for placements at the RS. Men with life sentences and serious violent convictions are also not eligible for ROTL placements at the RS.

The research for this article originates in two consecutive research fellowships, the second of which is on-going, in that I am still engaged with the RS for the purposes of interviewing trainees for the PeN project. The focus of the first research fellowship (SHI) (2015-16) was on commensality (eating together) as a tool for health, well-being, social inclusion and community resilience (Parsons 2017, 2018a). The RS where the research takes place is a fully independent, part community funded charitable incorporated organization. It was founded in 2013 and to date has worked with over 100 people, (approx., 50\% from the local prison). It is unique in its approach, offering individualised, bespoke support and training in a range of skills (e.g. cooking, construction, landscaping, market gardening, pottery, woodworking), alongside softer social skills and counselling. Men from the resettlement wing of the prison who have been given a ROTL are eligible to apply for a placement at the RS and come out from 6-12 months before the end of their prison sentences. Significantly for the purpose of the $\mathrm{SHI}$ research, people from the community visit the RS to share lunch with staff and trainees on a regular basis. Extensive field notes were kept during the fieldwork for the SHI project which was conducted over nine months in 2016. 
Following the SHI project, I received funding to develop a Photographic electronic Narrative (PeN) project. This was established over 2016-17, and is on-going, as I continue to work with trainees at the RS to create blog posts that document their time spent at the scheme (Parsons 2018b). The PeN project was developed with two interrelated aims, to enable trainees at the RS to create visual, self-reflective narratives about their time at the scheme, and to engage the wider community through online blog posts that included both photographs and autobiographical reflections. These posts are uploaded onto a bespoke website, which is promoted through social media platforms, Facebook, Twitter and Instagram (link to website here). These interviews are relatively unstructured, following issues of interest to participants. Given the aim is to follow their progress at the RS, some prisoners were interviewed more than once. The methodology followed a constructivist grounded theory approach, which is an iterative process, with data collection and analysis running concurrently (Charmaz 2006). For the PeN project, prisoners narrative accounts include reflections on the realities of life inside, for some this includes reference to food practices on the resettlement wing. There is a very small room on the ground floor, with a sink, worktop, fridge, toaster and microwave. An oven was installed within the last six months.

Across both fellowships I interviewed a total of 18 serving prisoners whilst they were on placement at the RS (six for the SHI project and twelve for the PeN project), which equates to a total of 39 interview transcripts (as some men were interviewed more than once for the PeN project). The sample selected for the purposes of this discussion include Paul, John and Ryan (interviewed during the SHI project) and Alfie, Benny, Frank, George, Lee, Matt and Terry (narrative interviews from the PeN project). These ten people were chosen as 'casestudies' as their narratives are illustrative of some of the ways in which prisoners counter the threats to self, imposed by prison foodways. The themes identified within the transcripts relating to food consider prison food as a threat to self because it is 'bad' food or as poison/contaminating because of the way it is prepared. In relation to prison foodways, themes centre on the ways in which prisoners maintain a sense of agency, autonomy and status through their use of the canteen and/or systems of bartering. They are also able to resist an isolating prison regime through forms of commensality (Parsons 2018a) and sharing food in order to counter the potential alienating impact of the institutionalised prison food system, which are also threats to self.

\section{Food in prison}

\section{Food as threat}

In this first section I consider the notion of 'food as threat', in terms of how prison foodways collapse traditional dichotomous approaches to what might be considered culturally normal or socially acceptable and the implications of this for individual identity. Here, following the HMIP (2016) report on food, prison foodways are generally considered to undermine a prisoner's dignity. For example, contrary to popular belief, prisoners do not eat communally in a canteen. Instead, all meals are eaten in the prisoner's cell, often alone and next to poorly screened toilet facilities. Prisoners have one cooked meal a day and 'packs.' These packs are essentially food/drink items put together in a pack for breakfast and lunch, as Terry explains: 
You have a breakfast-pack, which comes with milk and porridge, and that's in one pack. In that pack you get a tea-pack, which is tea-bags, whiteners and sugar. Also, in that pack, you get a milk and also a cereal bar, sort of thing, for the morning and maybe some porridge, or it could be muesli in there. So, you have that pack. That's called your breakfast-pack. You have that and your sandwich [pack] at dinner-time or an egg-pack, or a noodle-pack, or a sweet-pack. That's what you get. You don't get extra nothing. You can make your own sandwich. They give you two eggs, the roll comes with the noodle-pack or perhaps you get a soup in there as well, with the noodles. (Terry, PeN, 29:01, p7)

These packs are delivered every day but not necessarily consumed at breakfast or lunch time. In the HMIP (2016) report they identified how meals were generally served outside of regular mealtimes, with breakfast packs especially often eaten the night before, meaning prisoners spent long periods of time without food. This is challenging for people in prison in terms of breaking with the cultural norms and values around mealtimes as practiced outside of the prison estate. Time is also significant in terms of the reliance on food packs, instead of providing time-consuming cooked food at mealtimes. This has implications for identity, as convenience food is associated with lack of care (Parsons 2016) and the care and convenience antinomy (Warde 1997). In a neo-liberal era that values responsible individualism and healthy home-cooked meals, these packs become symbolic of the lowly status associated with being a prisoner. Moreover, they are reminiscent of distinctions between food that is prepared in order to demonstrate 'care' or being 'cared for' and food as a means of 'tending' to basic needs (DeVault 1991) as exemplified in institutional settings, such as the prison.

One way of countering the threat to self from the prison packs, for some people in prison if they have funds available, is to order food from the canteen, which:

...refers to a list of approved items available to purchase in prison every week. The main purchase prior to the smoking ban was rolling tobacco, but there are other items, such as tins of sardines/tuna. These are delivered to the cells in clear plastic bags each week. (Parsons, 2016b:05)

The number and types of items available on the canteen varies across the prison estate in England and Wales and can be a source of tension as items may be available in one prison and not another. People in prison also believe that items are more expensive on the canteen than they are on the outside, which adds to the sense that the prison is benefitting financially from their discomfort, as George comments:

I spend $f 20$ a week on food as well. My average canteen is $f 40$ to $£ 50$ a week, bananas, oranges, chicken curry, pittas, pasta, chocolate, Weetabix, breakfast. It's not cheap. We probably pay double to what you pay in the shops. Ripped off in some respects. (George, PeN, 24/05/18)

Here, George is able to counter the potential threat to his identity from the prison packs, by ordering healthier items, such as fruit and Weetabix, alongside treats like chocolate. This could be interpreted as an attempt to reify his identity as a responsible middle-class citizen, 
interested in a balanced diet. George was a former professional footballer, makes full use of the gym and sporting opportunities when available. His spending on the canteen marks him as different from others in that he can afford to spend $£ 20$ a week on food. His comment about being ripped off in this context, reinforces his position of difference, he is acknowledging that the extra cost is of little consequence. John and Ryan on the other hand complain about having to order even basic food items, such as tea, as the prison tea-bags are generally considered inferior quality. John and Ryan say that no-one uses the cheap (free) prison tea-bags, everyone buys their own. John says, "it is what it is" and then Ryan says "it is what it is" (SHI, 20/11/2015). This is a common refrain from prisoners, as they acknowledge that when it comes to care, and/or being cared for, as prisoners they have to accept that the usual cultural norms and values do not apply to them. That no-one cares how they are treated, as Ryan says, "at least it's not bread and water". However, being able to make use of the canteen enables them to express a sense of agency, autonomy and status and acts as form of resistance to the pains of imprisonment.

In terms of adapting to everyday prison foodways, further indignities are related to how food is eaten. For example:

...you get one bowl, one plastic plate, one plastic spoon and fork and you've got to look after them because you're not going to get another one in a hurry. If it goes missing it could be months before you get another one. (Frank, PeN, 28/09/2017)

These are issued to prisoners on arrival and as John says:

when you're in prison... you don't eat with metal knives and forks to start with. Everything's plastic. You don't sit down together to eat your dinner, everybody's back to their cells, eating on their own off their lap or whatever, or sat on the corner on your chair which is pretty crap really. (John, SHI, 10/12/2015)

This is material and symbolic punishment for John that reinforces his sense of deprivation. Providing plastic cutlery simultaneously enacts one of the pains of prison as indignity. It could also be argued that it challenges a middle-class cultural habitus or John's sensibilities regarding what is 'normal', socially and culturally acceptable to him. It reinforces the indignity for him of having become a prisoner. Prior to this comment he says:

My mother was always one for eating at the table and all laid out and I think we tended to do that at home really as well. At weekends the girls used to come around and we'd all sit down for Sunday dinner and that, which is quite nice. (John, SHI, 10/12/2015)

Here, he highlights how prison foodways are alienating to him, they fall outside of his usual cultural habitus and the 'rules' of family foodways that he inculcated in his life prior to incarceration. This can be seen to emphasise the role of food as a form of symbolic punishment (Sexton 2015). It marks him as different to other people in prison and might be considered a means of reifying a middle-class cultural habitus that is undermined by the prison regime. 
In Matt's account he also refers to his mum's cooking:

We're very lucky now. We've got a chap on there [resettlement wing] called $A^{*}$. He has trained to be a chef in prison. He's in for murder, butf\#*@, his pastry, honest to god. My mother made beautiful pastry, but he is ... he said, "that is my forte". He gets is so thin. It just dissolves in your mouth. He's been making ... in fact he's doing one this weekend, a cherry and apple pie. I get the apples from the supply when they come in. So, I save up my apples for him and he has them. Then I buy a tin of cherries from the canteen. (Matt, PeN, 30:1, p8)

For people in prison like John and Matt, prison foodways are a constant reminder of loss, of family foodways and home. They also represent opportunities to recreate food memories and to engage in reciprocal relationships, in an effort to counter the pains of the official prison food system and the assaults on cultural, social and individual identity. It is about recreating notions of caring through food and foodways in an effort to counter the alienating impact of institutionalised 'care'.

\section{Food as Poison}

Linked to the notion of food as threat, is food as poison, in both instances these symbolically mark the prisoner as unworthy of 'good' food/foodways. Again, this is about antinomies of taste, about convenience and not care and economy as opposed to extravagance (Warde 1997). Moreover, there is a hierarchy related to contamination, pollution and disgust (Douglas 1966). The food served is lacking in taste, can cause illness, is not fit for human consumption and/or past its sell by date. More significantly in this particular prison however is that the main meal is prepared by people who are considered to be at the bottom of the prison hierarchy, so the way food is prepared is dangerous, contaminating, polluting and elicits disgust (Douglas 1966).

In the SHI project the men in prison went to great lengths to explain how much the prison food and foodways elicited disgust. This works on a number of levels and supports the HMIP (2016) report on food in prison, in that the ways in which the food is prepared and served undermines a prisoner's dignity. To begin with food is prepared at a time convenient for the prison regime in the morning and is therefore not served fresh from the kitchen. Instead, it is left cooked in warming trays for hours and served at 5:00pm. There was general agreement amongst the men that prison food is 'tasteless', 'bland' and not fit for human consumption. However, there was also disagreement, as whilst some prisoners complained about the standards of food served, others acknowledged that they were in prison and therefore they argued that they could not expect to be served 'good' food. Ryan for example, commented on how prisoners in previous eras would have survived on bread and water. He did not like to complain about the food. Terry on the other hand was super vigilant when it came to his food, particularly about the potential for contamination from out of date food, he says:

When the trolley comes up every day from the kitchen to the wing, it comes up with bread as well, but you've got to watch the dates. You've got to keep your eye on the date because sometimes it's off. I know it hasn't been opened, but you just throw it into the bin. There's a lot of waste. (Terry, PeN, 29_1, p8) 
In John's account he says:

You get the better food at Christmas... it's not great, it's still like all the bottom of the range stuff and everything, but you do get a lotta, lotta food, they fill you up because they're locking you up early, that's what I think anyway, they're filling you up...

everything you get at home really but just not really nice... (John, PeN, 08/12/2016)

Here, whilst food at Christmas is marginally better, it is still inferior quality and 'bottom of the range'. It is also not a gift as it is tarnished with the threat of an early lock-up. In other words, whilst they have more food at Christmas, the regime is such that with limited staffing, they will spend more time locked up in their cells.

Food as poison - prepared by 'Forty-fives'

The importance of not eating what is available is heightened at this particular prison, as those who prepare the main meal of the day in the prison kitchens are prisoners from the Vulnerable Prisoner Unit (VPU). Colloquially, prisoners from this unit might be referred to as 'rule forty-fives', 'numbers', 'bacons' or simply 'VPUs'. One of the context specific issues in this prison therefore relates to a fear of contamination amongst regular prisoners, and the impact this has on everyday foodways. For example, Terry says:

In the evening you get an evening meal. It could be anything. It could be lasagne. It could be tuna pasta bake. It could be spaghetti Bolognese. You don't really eat them because they're more like a liquid. They [the VPUs] could pee in them, they could do anything, couldn't they? So, a lot of food gets thrown out because they're messing with it... If it's not in a pack, I really don't want it. The others [on the resettlement wing] are the same, most of them I think, or they cook on the wing. (Terry, PeN, 29_1, p7)

The perceived threat of contamination of the prison food by VPUs is a common theme and leads to a number of deliberate strategies employed by prisoners to avoid eating food that they think might be contaminated. This reinforces a hierarchical prison structure that prisoners perpetuate in order to position themselves as better than others. In order to protect themselves people in prison discursively conjure 'straw deviants' or others 'who confirm to the dominant stereotype and against whom they position themselves as moral' (Hannem and Brickert 2012: 04). Terry, continues:

On weekends I might go for lunch, which is beans and a sausage and some hashbrowns. That's downstairs. They bring it up from the kitchen, so they can't really mess about with it. The sausage, you can tell if it's been messed with because it would be broken or something like that and the ends are curved over, so, you can tell if it's been messed with. It's the same with the hash-browns. They're in a triangle. If it's broken or something like that, I chuck it in the bin and the beans... Beans are only $25 p$ from the canteen. I open my own beans, have half a tin of beans there and then have the other half of the tin at night with toast. (Terry 29_1, p7) 
Hence, avoiding food that might be contaminated in favour of food served in sealed packs is one strategy. Another strategy for avoiding potential contamination from food prepared by the VPUs is through bartering. Indeed, whilst researchers working in the field of prison foodways have described ways in which people in prison counter threats to self by resisting the official prison food system, for example 'kettle cooking' or brewing 'jailhouse hooch' (Ugelvik 2011, Parsons, 2016b, 2017), for some people, food in prison presents opportunities for trade. For example, Terry says:

What I do is, we also have a tea-pack and we get milk with that. It's called a breakfast pack with the tea-bags. They're rubbish tea-bags, and you get whiteners and sugar with it. So, I save my sugars until I've got 100 and then I sell them, swap them for something else. (Terry, PeN, 29:01, p3)

Later her says:

The same goes with the milk. Since I've been working out here, instead of getting one milk a day, I get two milk's a day because I get milk in my breakfast pack, which I don't eat. So, I've got one milk there and also, I get a ROTL pack as well when I come up here. We have a milk, apple, three biscuits in a pack and a packet of crisps. So, I save the milk out of there and I save some of biscuits and the crisps I don't really eat because they've got the wrinkles in them, they hurt my gums, so, I save them all up and I get rid of them for a bag of coffee or something like that. (Terry PeN, 29:01, p4)

In Terry's case, unlike other people in prison he does not have money coming in from the outside to supplement the income he has available to spend on the canteen. He has therefore learnt to save free items and to barter and exchange these with other people for the items he wants, such as coffee and baked beans. He says:

So, at tea-time you get a roast dinner. The potatoes are awful. The veg looks like dirt and you get a chicken with it and the stuffing. The stuffing's ok, the chicken, I give that to some body and they give me a tin of beans for it... So, if the gym boys want eggs, then I make a deal for them. I'll say "you have the eggs, you get me coffee". It's the protein, that's what they're looking for. I'll keep the crisps. (Terry, PeN 29_1, p7)

This is an example of how people in prison reinstate a sense of agency and autonomy in terms of their everyday foodways and resist contamination from food prepared by the VPUs. It is also about solidarity, as Terry and others position themselves as different to 'other' prisoners.

Food as solidarity and recompense

Another strategy for avoiding prison food and countering the impact of contamination and pollution is cooking for themselves and others. This offers men on the resettlement wing an opportunity for recompense for their low status as prisoners and solidarity as enhanced prisoners with privileges. This differs from others in this prison, as well as other prisons from across the estate in England and Wales, in that: 
On our wing we've got a cooker, an oven and we've got a microwave, a toaster. We've got a washing-machine and dryer. That's what we've got on our wing, but on the other wings, they haven't got none of that. They've barely got a toaster because somebody's nicked that as well. It's just one of them things really. I don't cook anything. (Terry PeN, 29:01, p8)

Here Terry is outlining the benefits of being on the resettlement wing as an 'enhanced prisoner'. Although, he claims not to cook anything himself, access to these facilitates means that he may get to share in what others are cooking/ preparing. He is also differentiating himself and his wing from others, where things are stolen. The assumption being that they are more civilised on their wing and the ability to cook/prepare their own food contributes to this. For many it also presents an opportunity for agency within a system that allows for very little in terms of choice, as Alfie explains:

I did a lovely corned-beef hash the other day... we got two tins and then they do these new potato spuds, not tinned, they come in and we've got rosemary in the garden and I ordered some garlic bulb... We've got an oven now, yeah. We've had that for probably three months. It's an oven, I wouldn't say it's a proper oven, but it'll do. We cook for a few people on the wings. You've got to nominate who you want to cook for. You pick and choose. (Alfie, PeN, 01/08/2018)

Here, Alfie is outlining his knowledge of ingredients; he uses garlic and rosemary. This highlights his access to what Naccarato and LeBesco (2012) refer to as culinary capital; a reworking of Bourdieu's (1984) thesis with a particular focus on elite food practices. Hence, Alfie is not just a prisoner but a cook, this potentially gives him some status and power, as he can nominate who he cooks for. Indeed, through cooking for others on the wing, Alfie is able to express some agency, autonomy and status. Cooking for others however, is not straight forward and often requires some kind of financial contribution, mainly the purchase of items for the meal from the canteen. Although, these arrangements are negotiated as Paul explains:

my friend next door goes in my cell and gets all the bits and cooks for me... we cook six days of the week, usually curries I think we've got spinach, mushroom, like a cheese sauce with tuna tonight... He cooks, he's a lifer... he cooks and yes... I pay for it all. That's the deal, he doesn't obviously get money sent in whereas I've got money to be sent in, rapidly running out, after 13 and a half months but yes... I buy us muffins for breakfast on Saturday and Sunday and we have malt loaf for lunch through the week and I buy loads of fruit that we can all eat when I say all, I mean me and him..." (Paul, SHI, 18: pp 9-.10)

This is a straightforward two-way relationship between Paul and his neighbour. In this arrangement although Paul says 'we' cook, it is on fact 'the lifer' who cooks a meal for them both every day, whilst Paul provides the ingredients, occasional treats and snacks. Other arrangements on the wing are a little more complicated and if people are looking to share food, a financial contribution to shared meals is expected, as Matt says: 
[The new chef on the wing] doesn't mind cooking for the rest of them if they chuck something in from the canteen, but they want their oils and vapes and all the rest of it. They spend their money on that and then say "oh Christ, we'd like some of that", I say "get your hand in your bloody pocket and you can have some" (Matt, PeN, 30:1, p8).

The contribution does not have to be from purchasing food from the canteen as Terry explains:

[Matt] makes a trifle every weekend. A few of us have trifle, me, Matt, Danny ... there's about four or five of us. It's normally on a Saturday afternoon or a Sunday evening. Matt will come around saying "do you want trifle?" and I'll say, "go on then", and then he'll go off somewhere, to his cell. If you tell one person, they might go around telling everybody, so they'd all want a bit. I might give him my square cake or something like that, that you have at night-times, or I'll buy tinned fruit. We all chip into it. (Terry, PeN 29_1, p8)

Through the preparation of meals for others, a sense of solidarity or sociability is made and remade through the sharing of food. This serves to counter the impact of institutionalisation; it enables prisoners to engage in social relationships and make individual choices based on their own tastes and preferences. The trifle is also a treat or an indulgence that sits outside of regular meal making but is no less significant in terms of defining the group. In this arrangement, it is only people invited into the group who share the food, and as Terry indicates, sometimes he might not be able to contribute with food such as tinned fruit from the canteen, so he saves up the square bits of cake the prison provide. However, what becomes clear is that cooking and sharing food is about relationships with others on the wing, gaining or maintaining status as providers or suppliers of food on numerous levels, whether it is meals, snacks or treats. It enables prisoners to engage in indulgent and extravagant food practices like they might on the outside. It is also an opportunity for sociability, that highlights 'the immeasurable sociological significance of the meal' (Simmel, 1997 [1910]:130), and defines who is 'in' or 'out' of the various groups. It also serves to counter some of the negative associations related to a prisoner identity, as Benny explains:

I like my cooking, yeah I cook five nights a week and I cook mainly for about five prisoners, sometimes six (Benny, PeN, 13/07/2017)

In this instance 'we' refers to the contributions made by others in terms of payment and/or contributions and also in the sharing and eating of the same food, which reinforces a sense of solidarity and sociability (Simmel 1997). Benny's status as a cook on the wing is also important to him, it counters some of the negative associations related to being in prison, he is doing something for others, there is a sort of reciprocity at work. He says:

...they look forward to it Jules. They don't stop talking about it. It's got to be alright. We all buy it, we all chip in, about $f 2$, it's not a lot, it does enough, but I struggle because the pasta, just cooking the pasta in the microwave that small in a washingup bowl because that's all I've got, it's tricky (68. Benny 21_6_18 (12_5) p14). 
For Benny therefore, whilst he complains about the work involved due to limited cooking facilities on the wing, he has power and control over who and what he cooks and there is some satisfaction for him in this. This presentation of himself as 'selfless' in cooking for others is also a useful means of countering negative perceptions of prisoners. Indeed, for prisoners on the resettlement wing, the privileges afforded to them that enable them to cook and prepare food for each other serves to reify their status in the prison hierarchy. They are not like other prisoners; they care about their food and foodways and gain a sense of solidarity and recompense through preparing, cooking and sharing food, which counters the contaminating effects of food as threat and poison.

\section{Conclusion}

Overall, narrative data from interviews with prisoners in this case study supports HMIP (2016) findings that "the quantity and quality of the food provided [in prison] is insufficient, and the conditions in which it is served and eaten undermine respect for prisoners' dignity" (2016:13). Indeed, across the prison estate in England and Wales the notion that prisoners should be fed well runs counter to the notion of the prison as a place where prisoners should be punished. The provision of food for prisoners is not designed to mirror everyday life and there is an expectation that the food should not be good. This has implications in terms of maintaining the marginalisation and alienation of the prison population from the 'free community' (HMIP, 2016:11).

In summary, food as threat and food as poison, highlights the extent to which inappropriate prison foodways (food served out of time, in poor environments, in inadequate settings) challenges some of the enhanced prisoners social and cultural norms and values. This then effects a prisoner's sense of self and identity. Food as solidarity and recompense on the other hand demonstrates how it is possible to use everyday foodways to reinstate a sense of self, to create and recreate cultural norms and values. Hence, some of the prison foodways as practiced on the resettlement wing reifies the status of the enhanced prisoner, their foodways signify privilege and marks them as different to 'other' prisoners. It enables an expression of agency, autonomy and status. Indeed, foodways are an additional means of improving an enhanced status, providing culinary capital (Naccarato and LeBesco 2012), which is important within a hierarchical system which positions prisoners pretty close to the bottom of the social hierarchy.

What connects these narratives is the lived experience of prison life on a particular wing of one prison, where lifestyles before prison influence the extent to which they express the 'pains of imprisonment' (Sykes 1958) as experienced through food. Notably, for some "it is what it is", and food is just another aspect of punishment that needs to be endured. For others complicated strategies are contrived to counter threats from contamination. Overall, the narratives demonstrate the power of everyday foodways even in a prison setting to create and recreate hierarchies and status, to enhance a sense of self. The foodways as practiced on the resettlement wing of this prison enables prisoners with an enhanced status to define themselves as better or at least not as bad as other prisoners. Foodways can be civilising processes and can enable socially excluded groups an opportunity to express an enhanced status. Some prisoners were thus able to strive for a middle-class cultural habitus, despite the prevailing counter-culture of the prison regime that provides convenience pre- 
packaged and arguably unhealthy meals. People in this study also highlighted how they negotiated ways of working against a prison regime that serves unpalatable and contaminated food, through bartering, purchasing food from the canteen and/or cooking/ preparing food for others. These strategies however are only possible for people on the resettlement wing, where the fear of losing an enhanced status and being "kicked-off" the wing is an ever-present threat.

References:

Barthes, R. (1979) Toward a psycho-sociology of contemporary food consumption', in R. Forster and O Ranum (eds) Food and Drink in History, Baltimore, Md: The Johns Hopkins University Press.

Beardsworth, A. and Keil, T (1997) Sociology on the Menu. An invitation to the study of food and society. London: Routledge

Bourdieu, P. (1984) Distinction, A Social critique of the Judgement of Taste, London: Routledge.

Carolan, M. (2011) Embodied Food Politics, Farnham: Ashgate

Charmaz, K. (2006) Constructing Grounded Theory, London: Sage

Crewe, B., Warr, J., Bennett, P., and Smith, A., (2014) The emotional geography of prison life, Theoretical Criminology, vol 18: issue 1, pp 56-74.

Counihan, M. (1999) The Anthropology of Food and Body, Gender, Meaning and Power, London, Routledge.

DeVault, M. I. (1991), Feeding the Family, London: University of Chicago Press

Douglas, M. (1966) Purity and Danger, An Analysis of Pollution and Taboo, London:

Routledge

Douglas, M. (1975) Deciphering a meal', Daedalus 101, 1:61-81

Douglas M (1984) Standard social uses of food: Introduction in M. Douglas (ed) Food in the Social Order: Studies of Food and Festivities in Three American Communities, New York: Russell Sage Foundation.

Eagleton, T. (1998), Edible écriture, in Griffiths, S and Wallace, J (eds) Consuming Passions, food in an age of anxiety, Manchester: Mandolin

Elias, N., (1978) The History of Manners. The civilising process: Volume 1, New York: Pantheon Books 
Godderis, R. (2006) Dining in: The Symbolic Power of Food in Prison, The Howard Journal, Vol 45 No 3, pp. 255-267

Goffman, E., (1961) Asylums: Essays of the Social Situations of Mental Patients and Other Inmates, New York, Doubleday: Anchor.

Goffman, E (1961b) On the characteristics of total institutions: The inmate world, in D Cressey (ed) The Prison, Studies in Institutional Organisation and Change, New York: Holt, Reinhart and Wilson.

Goffman, E. (1963) Stigma, Notes on the management of a spoiled identity, London: Penguin

Hannem S., and Bruckert, C., (2012) Stigma Revisited, Implications of the Mark, Ottowa, University of Ottowa Press.

Her Majesty's Chief Inspector of Prisons (2016) Life in Prison: Food, a Findings Paper, London: The Stationary Office

Jewkes, Y (2002) Captive Audience, Media, masculinity and power in prisons, Cullompton: Willan Publishing.

Jewkes, Y. (2012) Identity and adaptation in prison, in Crewe, B. and Bennett. J., (eds) The Prisoner, Routledge, London, pp40-52.

Jewkes, Y. and Johnston, H. (2006) Prison Readings, A Critical Introduction to Prisons and Imprisonment, Cullompton: Willan Publishing

Mennell, S. (1985) All Manners of Food, Blackwell: Oxford.

McNaughton Nichols, C., and Webster, S. (2018) The separated location of prisoners with sexual convictions: Research on the benefits and risks, Her Majesty's Prison and Probation Service. Accessed 04/03/2019

https://assets.publishing.service.gov.uk/government/uploads/system/uploads/attachment data/file/749149/separated-location-prisoners-with-sexual-convictions-report.pdf

Naccarato, P. and LeBesco, K. (2012) Culinary Capital, London: Berg.

Parsons, J.M. (2018b) Virtual social media spaces, a relational arena for 'bearing witness' to desistance, Papers from the British Criminological Conference 2018, Vol 18, http://www.britsoccrim.org/papers-from-the-british-criminology-conference-2018/

Parsons J.M. (2018a) Commensality as a theatre for witnessing change for criminalised individuals working at a resettlement scheme, European Journal of Probation, Volume 10, Issue 3, pp 182-198

Parsons, J.M. (2017) Cooking with Offenders to improve health and wellbeing. Special issue of the British Food Journal on Cooking, Health and Evidence, Vol 119, Iss 5, pp 1079-1090. 
Parsons, J. (2016b) (Editor) "It is What it is", LandWorks Recipe Book, Volume 1, CatsSolutions, Swindon.

Parsons, J. (2016a) When convenience is inconvenient, 'healthy' family foodways and the persistent intersectionalities of gender and class, Journal of Gender Studies, Vol 25, Iss 4, pp 382-397.

Parsons, J. M. (2015) Gender, Class and Food: families, bodies and health, Palgrave MacMillan: Basingstoke.

Parsons, J. (2014) 'Cheese and Chips out of Styrofoam Containers': An Exploration of Taste and Cultural Symbols of Appropriate Family Foodways, Media/Culture Journal, vol.17, No. 1 - 'taste' (unpaginated)

Sexton L (2015) Penal subjectivities: Developing a theoretical framework for penal consciousness. Punishment \& Society 17(1): 114-136.

Simmel, G. (1997 [1910]), The Sociology of the Meal, in G. Simmel (ed), Simmel on Culture: Selected Writings, pp130-6, London: Sage

Smoyer, A.B and Lopes, G. (2017) Hungry on the inside: Prison food as concrete and symbolic punishment in a women's prison, Punishment \& Society, Vol. 19(2) 240-255

Sykes, G.M. (1958) The Society of Captives, Study of a Maximum Security Prison, Princeton: Princeton University Press

Ugelvik, T. (2011) The hidden food: Mealtime resistance and identity work in a Norwegian prison, Punishment \& Society 13(1) 47-63.

Valentine, G., and Longstaff, B., (1998), Doing Porridge, Food and Social Relations in a Male Prison, Journal of Material Culture, Vol 3, Iss 2, pp.131-152

Visser, M. (1991) The Rituals of Dinner, New York: Penguin.

Warde, A. (1997) Consumption, Food and Taste, London: Sage.

Warde, A. (2016) The Practice of Eating, Cambridge: Polity Press 